\title{
O RECONHECIMENTO DE SI COMO CONDIÇÃO DO RETORNO EM HOMERO E EM GUIMARÃES ROSA
}

Clarissa Catarina Barletta Marchelli é mestranda no Programa de Pós-Graduação em "Literatura, Cultura e Contemporaneidade", da PUC-Rio. E-mail: clarissa.catarina@gmail.com

\section{Resumo}

O presente artigo compara semelhanças e diferenças do retorno para casa, tema da Odisseia, de Homero, e do conto $O$ recado do Morro, de Guimarães Rosa. O empreendimento se viabiliza sob a condição do reconhecimento de si, conforme argumenta Paul Ricoeur (2006, p. 92): “[...] fazer-se reconhecer é recuperar seu domínio ameaçado". Quando da escuta de uma canção, ambos os heróis resgatam e afirmam cada um a sua identidade.

\begin{abstract}
This article compares similarities and differences in returning home, theme of the Odyssey of Homer, and the tale The message of the hill of Guimarães Rosa. The project is made possible under the condition of self-recognition, as argued by Paul Ricoeur (2006, p 92): "[...] To be recognized is recover your threatened domain." When listening to a song, both heroes redeem and claim each one his identity.
\end{abstract}

\section{Este estrangeiro que vedes - ignoro-lhe o nome - buscou-me, \\ ou do nascente errabundo, ou dos homens que ficam no ocaso. \\ Súplice, pede que à pátria o enviemos por modo seguro.}

Homero, Odisseia, VIII, 28-30 1

A epígrafe acima é parte da fala de Alcínoo, rei dos feácios, quando da acolhida ao herói Odisseu, tendo este sobrevivido aos desejos da deusa Calipso de manter-lhe prisioneiro. E o estrangeiro a quem Alcínoo se refere não é ninguém menos que o próprio Odisseu que, liberto das vontades da deusa, aporta na ilha da Esquéria na tentativa de voltar para Ítaca. Espécie de lugar limítrofe entre o mundo dos deuses e o mundo dos homens, a ilha dos feácios é decisiva para o retorno do herói, pois será o mais nobre povo que proverá o náufrago com a devida embarcação ${ }^{2}$. Ainda sobre a estadia do protagonista da épica na ilha de Ogígia, comenta Fernando Muniz (1998, p. 33):

O próprio nome da deusa, de antemão, indica o procedimento que usa para a retenção do herói: do verbo kalýptein, 'esconder', Calypso é aquela que esconde, que oculta. Mas se, por um lado, a deusa esconde Odisseu dos olhos dos outros mortais, por outro, ela procura ocultar do herói seu próprio anseio de reencontrar o caminho de volta para casa.

Antes, porém, que Alcínoo disponha do navio para Odisseu, oferece ao hóspede um banquete, forma pela qual os gregos dos tempos homéricos demonstravam receptividade. Muitos são os convidados da festa, incluindo o bardo Demódoco que

\footnotetext{
${ }^{1}$ Cf. HOMERO, Odisseia. Trad. Carlos Alberto Nunes. RJ: Ediouro, 2002.

${ }^{2}$ HEUBECK, A., WEST, S. e HAINSWORTH, J. B. A commentary on Homer's Odyssey, v. I. Oxford: Claredon, 1991, p. 342. "The world of Scheria is thus a Homeric world from wich war, the curse as well as the glory of the heroic age, has been removed (vi 200). At the same time it is the sort of toilless world for wich Hesiod yearned [...]. The natural amenities of Scheria, peace, leisure, abundant crops, are dreams special to no time and place: they were shared by Hebrew prophets (Isaiah 2: 2-4, Micah 4: 1-5) and classical poets (A. Suppl. 625-709, Eu. 937-87) alike.
} 
alegra o festim com suas canções acerca da própria guerra de Troia. Com elas o homem que ainda não revelara sua identidade ao rei se comove, ouvindo do aedo a narração da disputa que ele mesmo uma vez travara com o rival Aquiles. O astuto Odisseu também chora ao ouvir o próprio episódio do cavalo de madeira, estratégia planejada também por ele que permitiu a vitória grega sobre os troianos. Eis a descrição que o poeta faz da alteração emocional que sofre o guerreiro nessa escuta:

Isso narrava o famoso cantor. Odisseu, entrementes, liquefazia-se em lágrimas, tendo banhadas as faces, como mulher abraçada no corpo do caro marido que sucumbisse a lutar junto aos muros e seus moradores, a defendê-la e a seus filhos da sorte do dia impiedoso. (HOM., VIII, 521-5).

Ante a alteração do estrangeiro com o teor das canções de Demódoco, e ainda disposto a conceder o navio para o náufrago, Alcínoo pede ao hóspede a revelação da sua identidade:

Dize teu nome, e de como o teu pai e tua mãe te nomeiam na tua pátria, assim como os vizinhos, que em volta demoram. Não há ninguém desprovido de nome na face da terra, desde que nasce, quer seja de nobre prosápia, ou do povo. Sim, desde o início se afanam na escolha do nome seus pais. Quero, também, que me digas a terra, a cidade e teu povo, para que a nau te conduza, mercê do seu próprio intelecto, pois os navios dos homens feácios diferem dos outros. ${ }^{3}$ (HOM., VIII, 549-50).

Somente agora, após o resgate da querela com Aquiles e da emboscada do cavalo de madeira, é que o herói da Odisseia pode se fazer reconhecido e, consequentemente, dar o primeiro passo na reconquista do seu lugar no mundo dos homens: "Sou de Laertes o filho, Odisseu, conhecido entre os homens / por toda sorte de astúcia; bater foi no céu minha glória" (HOM., IX, 19-20)

Acerca da fiabilidade da identidade de Odisseu, inúmeras vezes atestada ao longo da Odisseia, vale-se Paul Ricoeur para fundamentação de sua teoria sobre o reconhecimento:

A famosa narrativa do retorno do Ulisses a Ítaca é sem sombra de dúvida uma narrativa do reconhecimento cujo herói é ao mesmo tempo o protagonista e o beneficiário. [...] A narrativa não é a de um reconhecimento mútuo. Mas há uma razão mais decisiva que impede essa narrativa de ultrapassar o limiar para a reciprocidade: as cenas de reconhecimento balizam a reconquista de sua própria casa por um mestre inflexível, à custa de usurpadores que têm a postura de pretendentes à posse da esposa legítima. [...] Um esposo será reconhecido, mas, nesse impulso, um mestre será restabelecido na plenitude de seu domínio (RICOEUR, 2006, p. 90).

\footnotetext{
${ }^{3}$ Cf. Id., ib. p. 383: "The oikonomía of the Odyssey makes it convenient to pass from the Phaeacians, है $\sigma \chi \alpha \tau$ or of man (vi 205), to the real world of Ithaca in a single night. The magic ships may therefore be no more than a happy invention to accomplish that end, in keeping with a land that kwons no toil. 
Em Percurso do reconhecimento (2006), o teórico francês discorre sobre os vários casos de reconhecimento da identidade de Odisseu ocorrentes na épica, dentre os quais destaca os reconhecimentos operados pelo filho, pelo caseiro, pelo cachorro e pela própria esposa, Penélope. Eis a cena do reencontro dos esposos que, por sua vez, salienta a reação de Penélope, ao ter confirmada a identidade do marido após revelação do segredo compartilhado pelo casal:

Tal como a vista da terra distante é agradável aos náufragos, quando, em mar alto, o navio de boa feitura Poseidon faz soçobrar, sob o impulso dos ventos e de ondas furiosas; poucos conseguem chegar até o firme, nadando nas ondas de cor escura, com os membros cobertos de espessa salsugem, e ledos pisam na praia, enfim tendo da Morte escapado; do mesmo modo a Penélope a vista do esposo era cara, sem que pudesse dos cândidos braços, enfim, desprendê-lo.

(HOM., XXIII, 233-240)

Espécie de ápice argumentativo para a teoria de Ricoeur, o reconhecimento operado por Penélope também nos interessa em particular para vislumbre de um reconhecimento mútuo pré-existente em Homero - mesmo que embrionário. Porém, quer nos parecer que importa mais para Ricoeur a sequência com que o protagonista da épica é reconhecido pelos demais personagens secundários através de sinais que lhes confirmam a identidade do herói, que uma eventual reciprocidade no processo do reconhecimento. Esta reciprocidade parece se esboçar no episódio do teste do leito, no qual Penélope insinua que a cama do casal, outrora fixa, está agora fora do quarto. Vejamos a cena:

"Mas enfim, seja! Euricleia, prepara-lhe o sólido leito fora do quarto de bela feitura construído por ele.

A cama, pois, lhe prepara do lado de fora e a recobre com boas peles e mantos e colchas de linha esplendente."

Isso disse ela, com o fim de provar o marido. HOM., XXIII, 177-81)

Sobre o teste do leito, comenta Paul Ricoeur: "Penélope sabe que o leito nupcial foi talhado por ele no tronco de uma oliveira plantada no solo. Admirável sinal do segredo compartilhado: 'A maneira desse leito era meu segredo' (XXIII, 187)” (2006, p. 82). Conclui o filósofo:

O que podemos reter para nossa pesquisa? Personagens homéricos aos quais permitimos que se comportassem como 'centros de decisão' (Odisseu decide voltar para casa, recusando a pedido de casamento da deusa Calípso, o que lhe garantiria vida eterna) e que 'se reconhecem como responsáveis' também são capazes de um reconhecimento que passa por outrem, mas que ainda não pode ser considerado mútuo, de tão centrado que está em um único protagonista e limitado ao papel que a tradição atribui a cada pessoa na periferia do mestre. Para esse mestre, fazer-se reconhecer é recuperar seu domínio ameaçado. (2006, p. 92). 
A despeito de o filósofo refutar a possibilidade de um mútuo reconhecimento entre os esposos que não se vêem há vinte anos, é inevitável a comparação entre os símiles que descrevem os estados psíquicos de cada um ao obter do outro a confirmação da própria identidade. O sofrimento de Odisseu é comparado ao sofrimento de uma mulher que perde o marido em batalha - o próprio Odisseu na guerra de Troia; e o sofrimento dela, por sua vez, comparado ao alívio do náufrago que se salva - o próprio retorno de Odisseu.

Embora nos seja possível estabelecer um paralelo entre as reações de comoção dos esposos e dela deduzir uma mutualidade, ainda que indireta, importa menos para a nossa investigação a plausibilidade de um reconhecimento mútuo embrionário no mundo da Odisseia, que a viabilização do reconhecimento de si enquanto dado ou vindo de um outro, mais precisamente dado e vindo de uma narrativa ficcional. Tal é o caso da passagem de Odisseu pela ilha de Alcínoo, momento em que o herói pode resgatar publicamente sua identidade devido à simpatia pelas canções de Demódoco - simpatia essa flagrada pelo rei Alcínoo. Somente após a escuta dos episódios da disputa com Aquiles e da emboscada do cavalo de madeira é que Odisseu pode se fazer reconhecido e pode, enfim, transpor sua estadia no mundo dos deuses de volta ao mundo dos homens.

Poderíamos nos contentar com essa análise do canto VIII da Odisseia caso quiséssemos apenas especular o modo como se dera um relativo desligamento da origem das ações do homem em relação ao plano divino, a saber, a decisão de Odisseu pelo retorno à terra natal em detrimento da proposta de uma imortalidade anônima (matrimônio com Calipso) - gesto que inaugura na tradição ocidental a noção de responsabilidade sobre os próprios atos, como comenta o helenista Vidal-Naquet sobre o comportamento casto de Penélope, contraparte da decisão de Ulisses:

Durante quase toda a narrativa, desde o início do poema, Penélope é diferenciada da mulher adúltera, aquela que tomou um amante na ausência do marido e que, quando do retorno deste último, faz com que seja assassinado: Clitemnestra, a esposa maldita de Agamêmnon. Zeus evoca a sua história no início do poema para isentar os deuses de toda responsabilidade nesse crime, e o próprio Agamêmnon, no Hades, faz o relato desse drama para Ulisses, que não conhecia o seu fim (Vidal-Naquet, P. $O$ mundo de Homero. Trad.Jônatas Batista Neto. SP: Cia das Letras, 2002. p. 83).

A respeito da noção de responsabilidade sobre as próprias deliberações que se esboça no mundo da Odisseia, podemos atestá-la logo no canto de abertura do poema, quando Zeus abre o conselho dos deuses sobre o retorno do herói: "Caso curioso, que os homens nos culpem dos males que sofrem! / Pois, dizem eles, de nós lhes vão todos os danos, conquanto / contra o Destino, por próprias loucuras, as dores provoquem." 4 (HOM., . I, 32-4).

\footnotetext{
${ }^{4}$ Cf. HEUBECK, op. cit., p. 77: "A certain degree of suffering is part of the human condition, since men are exposed to forces outside their control, and for this, in terms of Homeric theology, the gods must be held responsible. Zeus does not attempt to deny this; his point is that men bring further troubles upon themselves by their own folly and perversity."
} 
Inquieta-nos, contudo, o modo como essa mesma responsabilidade foi sendo articulada, tendo em vista o descrédito da religiosidade homérica sucedido no séc. V e retratado pela tragédia ateniense. Para uma melhor compreensão da passagem do paradigma homérico ao homem trágico, recorremos aos helenistas J.P. Vernant e P. Vidal-Naquet, em Mito e tragédia na Grécia antiga:

O brusco aparecimento do gênero trágico no fim do século VI, no momento em que o direito começa a elaborar a noção de responsabilidade distinguindo, de maneira ainda desajeitada e hesitante, o crime 'voluntário' do crime 'escusável', marca uma etapa importante na história do homem interior: no quadro da cidade, o homem começa a experimentar-se enquanto agente, mais ou menos autônomo em relação às potências religiosas que dominam o universo, mais ou menos senhor de seus atos, tendo mais ou menos meios de agir sobre seu destino político e pessoal. Essa experiência, ainda flutuante e incerta, daquilo que será na história psicológica do ocidente a categoria da vontade, exprime-se na tragédia sob forma de uma interrogação angustiante, referindose às relações do homem com seus atos: em que medida o homem é realmente fonte de suas ações? Mesmo quando parece tomar a iniciativa e assumir a responsabilidade delas, não têm elas em algum lugar fora dele sua verdadeira origem? Sua significação não permanece em grande parte opaca àquele que as pratica, de tal sorte que é menos o agente que explica o ato, mas antes o ato que, revelando depois seu sentido autêntico, volta-se contra o agente, esclarece sua natureza, descobre o que ele é, e o que ele realmente realizou sem o saber. Esta íntima ligação entre um contexto social onde os conflitos de valor aparecem insolúveis e uma prática humana tornada inteiramente 'problemática', por não poder exatamente situar-se na ordem religiosa do mundo, explica que a tragédia seja um momento histórico muito precisamente localizado no espaço e no tempo (2005, p. 55-6)

A constatação dos helenistas da relativa autonomia do homem sobre seus atos, esboçada pela tragédia, suspende a solidariedade da vontade divina às decisões humanas, típica da tradição épica homérica. Ainda sobre a mesma noção de responsabilidade, positivamente caracterizada e na qual se insere o retorno de Odisseu, tema inaugural da Odisseia em relação à Ilíada, discorre Ricoeur:

Minha tese nesse plano é a de que existe um parentesco semântico estreito entre a atestação e o reconhecimento de si, na linha do "reconhecimento da responsabilidade" atribuído aos agentes da ação pelos gregos, de Homero e Sófocles a Aristóteles: ao reconhecer ter cometido um determinado ato, os agentes atestavam implicitamente que eram capazes de cometê-lo. A grande diferença entre os antigos e nós é que levamos ao estágio reflexivo a junção entre a atestação e o reconhecimento no sentido do “considerar verdadeiro". (2006, p. 107-8).

O que Paul Ricoeur parece defender na passagem de um momento a outro na história do ocidente é a consolidação de um tipo de compreensão dos atos em si a partir do deslocamento dos mesmos "para a instância do agente". Em outras palavras, tal abstração confere às ações serem provenientes de alguém, o que implica a noção de verdade enquanto traço de uma consciência que se reconhece nas próprias potencialidades, a saber: (1) poder dizer; (2) poder fazer e (3) poder narrar/narrar-se. 
Verdade em grego se diz alétheia $a^{5}$ cuja etimologia deixa transparecer a espiritualidade homérica: da raiz morfológica do rio Lete, o rio do esquecimento, somada ao alfa privativo; donde se tem verdadeiro, em grego, é aquilo que não pode ser esquecido, é o descoberto. Sobre o emprego decorrente da etimologia, encontramos em Grimal o índice de evolução do vocábulo:

LETE. $(\Lambda \eta ́ \theta \eta)$ Lete, o Esquecimento, é filha de Éris (a Discórdia) e, segundo uma tradição, mãe das Cáritas (as Graças). Deu o seu nome a uma fonte, a Fonte do Esquecimento, situada nos Infernos, de que os mortos bebiam para esquecer a sua vida terrena. De igual modo, na concepção dos filósofos, de que Platão se fez eco, antes de regressar à vida e de retomar um corpo, as almas bebiam desse líquido, que lhes tirava a memória do que tinham visto no mundo subterrâneo. (2000, p. 274-5).

Contemporaneamente, o filósofo Martin Heidegger, em Sobre a essência da verdade, lança mão da concepção clássica de "verdade", a saber, a coincidência do enunciado com o seu referente:

Se traduzirmos a palavra alétheia por "desvelamento", em lugar de "verdade", esta tradução não é somente mais "literal", mas ela compreende a indicação de repensar mais originalmente a noção corrente de verdade como conformidade da enunciação, no sentido, ainda incompreendido, do caráter de ser desvelado e do desvelamento do ente (citado por OS PENSADORES, 1979, p. 138).

Diferentemente para os modernos, verdade é como aquilo que a consciência de si acusa. E, segundo Ricoeur, a consciência de si acusa pode ser descrita nestes três modos:

(1) Na expressão "eu digo que", o "eu" não figura como um termo lexical do sistema da língua, mas como uma expressão auto-referencial por meio da qual designa a si mesmo aquele que, ao falar, emprega o pronome pessoal na primeira pessoa do singular. A esse título, ele é insubstituível ${ }^{6}$. (2006, p. 111);

(2) [...] que designa a capacidade de fazer ocorrer acontecimentos no ambiente físico e social do sujeito que age. Desse "fazer ocorrer" o sujeito pode se reconhecer como a "causa" em uma declaração do tipo: fui eu que fiz. É o que o personagem homérico e o herói trágico eram capazes de afirmar. Para nós, modernos, essa frase de apropriação perdeu sua inocência; ela deve ser reconquistada com operações de objetivação que alinham os acontecimentos que se faz ocorrer intencionalmente sobre os acontecimentos que simplesmente ocorrerem (2006, p. 111-112).

O que está em questão na definição de um poder fazer como expressão do reconhecimento da verdade é justamente a intencionalidade do seu sujeito, palavra de

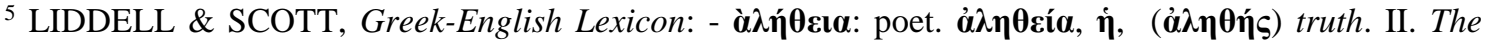
character of one who speaks truth, frankness, sincerity. - $\dot{\alpha} \lambda \eta \theta \dot{\eta} \varsigma, \dot{\varepsilon} \varsigma,(\alpha$ privat., $\lambda \eta \dot{\theta} \theta \omega)$ : without reserve: of persons, true, sincere; truthful, frank, honest: of things, real, actual.

${ }^{6}$ Curioso, aqui, é notar a ausência da ocorrência do pronome pessoal $\dot{\varepsilon} \gamma \omega ́$, correspondente ao nosso eu, em toda poesia homérica, tendo sido registrado apenas mais tarde, em Hesíodo, no poema $O$ trabalho $e$ os dias: "A ti boas coisas (eu) falarei, ó Perses, grande tolo!" (HESÍODO, 2006, p. 43.) 


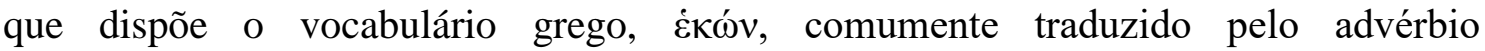
espontaneamente, mas que ainda não dimensiona uma escolha, um juízo ou uma deliberação. Simultaneamente, o mesmo universo semântico também conta com uma forma verbal muito cara e particular aos gregos, $\tau \vartheta \gamma \chi \alpha ́ v \omega$, e de difícil correspondência nas línguas modernas: acontecer por acaso. Deduz-se disso que o homem grego, embora agisse de bom grado, encontrava-se de antemão envolto em um cenário, vendo-se parte integrante do mesmo e passível de suas circunstâncias.

Terceira e última potencialidade traço de uma consciência que se materializa no eco daquilo que se considera verdadeiro, o poder narrar/narrar-se, segundo Paul Ricoeur, é cabal para uma compreensão do que ocorrera com Odisseu na escuta das canções de Demódoco, o aedo dos feácios:

(3) Sob a forma reflexiva do "narrar-se", a identidade pessoal se projeta como identidade narrativa. [...] Por ocasião da epopéia e da tragédia, Aristóteles elaborou sua noção de "pôr em intriga" (muthos) visando à "representação" (mímesis) da ação. Pôr em intriga atribui uma configuração inteligível a um conjunto heterogêneo composto de intenções, de causas e de acasos; a unidade de sentido resultante se baseia em um equilíbrio dinâmico entre uma exigência de concordância e admissão de discordância que, até o desfecho da narrativa, colocam em perigo essa identidade de um gênero único; o poder de unificação assim aplicado à dispersão episódica da narrativa não é outro que a própria "poesia" (2006, p. 114).

Se, ao ouvir de um bardo a intriga que uma personagem uma vez tivera com outra, e que a mesma depois conseguira tomar a cidade de Troia, tendo concebido um dolo (o cavalo de madeira cujo bojo abrigava os guerreiros gregos), o estrangeiro diante de Alcínoo se desfaz em lágrimas como uma mulher que perde o marido em batalha, é mister admitir que o hóspede de Alcínoo se vê fidedignamente projetado na narrativa do aedo, sentindo-se finalmente capaz de revelar sua verdadeira identidade, Odisseu, filho de Laertes. Estamos nós, agora, a um passo de acrescentar ao par verbal narrar/narrar-se um terceiro modo: o ser narrado, instância sob a qual "[...] um leitor pode declarar reconhecer-se em um determinado personagem tomado em uma determinada intriga" (RICOEUR, 2006, p. 115).

Não queremos com a análise dos cantos de Demódoco propor uma nova linha hermenêutica para a tradição dos estudos helênicos à luz da teoria do reconhecimento de Paul Ricoeur, isto é, a cena narrada em Homero não pode ser submetida exclusivamente à verificação segundo os argumentos do filósofo, numa correspondência unilateral. Ao longo da história da literatura, a poesia homérica se desdobrou em muitos outros gêneros, o que exige do helenista cuidado e apuração dos eventos que de fato tiveram lugar na distante Hélade. Nossa intenção é tão somente demonstrar em que medida uma narrativa ficcional é dotada de descobertas de aspectos que concernem ao plano da realidade. Tais revelações ecoam no interior de determinado leitor, numa espécie de reverberação do texto lido no âmago do seu receptor. Temos ciência de que a teoria do filósofo contemporâneo pretende dar conta de algo que excede ou mesmo extrapola a própria noção de identidade; visando à pedra angular em que se fundamenta uma vida 
em sociedade, a saber, o reconhecimento da própria identidade enquanto réplica do reconhecimento da identidade de outrem. Queremos, com Paul Ricoeur, por em relevo no gênero literário aquilo que de mais concreto ele parece ter assegurado: a verossimilhança, e com essa noção defender a plausibilidade da interpretação de uma narrativa de ficção que no mínimo suspeita de algo no plano real, ou seja, que acessa a realidade a partir de vestígios no próprio corpo literário.

Tal é o que parece se dar com o personagem Pedro Orósio, protagonista do conto $O$ recado do morro, de Guimarães Rosa, que sonha acordado com a seguinte cena:

Um homem chega à porta de sua casa, se rindo de si e escorrendo água, desvestia pesada a croça de fibra de palmeira boa. E uma mulher moça, dentro de casa, se rindo para o homem, dando a ele chá de folha de campo e creme de cocos bravos. E um menino, se rindo para a mãe na alegria de tudo, como quando tudo era falante, no inteiro dos campos gerias... (ROSA, 2001, p. 100).

O conto trata de uma expedição científica pelo sertão mineiro de um pesquisador alemão, acompanhado de um padre e um fazendeiro, "três patrões, entrajados e de limpo aspecto, gente de pessoa" (ROSA, 2001, p. 28). Por contraste, o guia dessa jornada é Pedro Orósio, alguém que bem conhece o território, sem nunca tê-lo estudado. Além de Pê Boi, segue também outro lavrador, igualmente desprovido de qualquer conhecimento teórico. Diante de pessoas relativamente cultas, compara-se Pedro Orósio:

De certo, segredos ganhavam, as pessoas estudadas; não eram para o uso de um lavrador como ele, só com sua saúde para trabalhar e suar, e a proteção de Deus em tudo. Um enxadeiro, sol a sol debruçado para a terra do chão, de orvalho a sereno, e puxando toda força de seu corpo, como é que há de saber pensar continuado? E, mesmo para entender ao vivo as coisas de perto, ele só tinha poder quando na mão da precisão, ou esquentado - por ódio ou por amor. Mais não conseguia. (ROSA, 2001, p. 35).

Voltemos à narrativa que se inicia quando a expedição já está chegando ao fim; ao longo dela, no entanto, o guia Pê Boi reflete sobre a própria vida em forma de solilóquios, como se se dispusesse a entrar em conformidade com uma vontade interior. Esses solilóquios, por sua vez, parecem ser a única formulação imagética, ou "eventos de pensamento" - para usar uma expressão de Paul Ricoeur, de que Pedro é capaz de realizar. Flagra da sua única atitude reflexiva, os solilóquios operam como que digressões ao seu lugar de origem, difusas no anseio pelo casamento. Mais, a frequência com que Pedro se visualiza casado chega a ser dissonante com seu estado civil de fato: solteiro.

[...] Pedro Orósio entrava repentino num imaginamento: uma vontade de, voltando em seus Gerais, pisado o de lá, ficar permanecente, para os anos dos dias. Arranjava uns alqueires de mato, roçava, plantava o bonito arroz, um feijãozinho. Se casava com uma moça boa, geralista pelo também, nunca mais vinha embora... Era uma vontade empurrada ligeiro, uma saudade a ser cumprida (ROSA, 2001, p. 47). 
A respeito do itinerário da expedição concomitante com aquilo que internamente tece Pedro Orósio nas brechas de uma estadia e outra, comenta a diplomata Heloisa Vilhena de Araujo, em A raiz da alma:

\begin{abstract}
A narração acompanha - constitui à medida que narra - uma viagem de ida e de volta. Por onde? Por um lado, é uma viagem que vai da região de Cordisburgo e Maquiné, em Minas Gerais, até os gerais que entram por Goiás, e de volta. Por outro lado, trata-se de uma viagem para o interior, para o país natal, para o passado, para dentro, e de volta. $\mathrm{O}$ direito da narração narra a paisagem de Minas e dos confins de Goiás. O avesso, invisível - o interior - não é narrado diretamente: é inferido a partir do direito. Este avesso da descrição da paisagem de "O recado do morro" é, se prestarmos atenção, o autor que narra: por detrás da estória está seu contador - está Guimarães Rosa. O direito e o avesso da viagem formam, portanto, conjugados, uma viagem de fora para dentro de Minas, neste caso, para o interior: para a lembrança da viagem, isto é, para a viagem interiorizada, contada. É a viagem do mundo real (Minas) para o da imaginação (conto). A narração está estreitamente articulada ao que é narrado: nasce do que é narrado e, ao mesmo tempo, o cria - formula-o em outro nível. Trata-se, portanto, de uma viagem por fora e por dentro ao mesmo tempo: pelo direito e pelo avesso. Trata-se de uma viagem de fora para dentro e de dentro para fora: do visível para o invisível e do invisível para o visível. (1992, p. 86).
\end{abstract}

Assim é que, a certa altura inquirido pelo cientista se era casado ou não, e sem condições de responder-lhe, frei Sinfrão faz um juízo da situação afetiva de Pê Boi ao pesquisador:

Que o Pedro era ainda teimoso solteiro, e o maior bandoleiro namorador: as moças todas mais gostavam dele do que de qualquer outro; por abuso disso, vivia tirando as namoradas, atravessava e tomava a que bem quisesse, só por divertimento de indecisão. Tal modo que muitos homens e rapazes lhe tinham ódio, queriam o fim dele, se não se atreviam a pegá-lo era por sensatez de medo, por ele ser turuna e primão de força, feito um touro ou uma montanha. Aquele mesmo Ivo, que evinha ali, e que de primeiro tão seu amigo fora, andava agora com ele estremecido, por conta de uma mocinha, Maria Melissa, do Cuba, da qual gostavam. (ROSA, 2001, p. 32-3).

Rivalidade com os demais camaradas: eis o mote pelo qual Pedro quase cai numa emboscada, não fosse pela inspiração poética do violeiro Pulgapé, alcunha do violeiro Laudelim, a alertar-lhe a respeito. Assim se dá a passagem na qual o cancioneiro sente o impulso para a composição ao ouvir o relato do Coletor sobre o imprevisto sermão do ex-seminarista, Nomindômine:

Mas o Laudelim cismara tanto e tanto, enquanto estava ouvindo, seu rosto se ensombreceu, logo se alumiou ainda mais. Cá que não esperava, ele propunha assim desses esquisitos. Ave, matutava. E mesmo, quando o Pedro Orósio o pegou pelo braço e ia levando, ele entreparou, asseteado, pé no ar. -"Isso é importante!" - disse. E pendurou cara, por escutar mais. - “... O extraordinário de importante... Tremer as peles... Cristãos sem o que fazer... Quero ver meu ouro... Um danado de extraordinário!...” O que? A tontaria do Coletor? Patarata! Mas, que é que se havia, se o Laudelim era mesmo assim - que dava de com os olhos não ver, ouvido não escutar, e se despreparava todo, nuvejava. Nunca se sabia de seus porfins. Ainda, ainda. E a-duro vinha vindo, mas quebrou para a banda da casa do Siô Tico, de onde se avistava todo o arraial, lá em baixo, e a várzea. - "Vou mais no cemitério não. Já achei..." Que é que 
podia ter achado? Se sentou debaixo do itapicurú, temperava o violão, apalpou as cordas. Com ele desse jeito, arredado crente, boas horas de perdidas se podia ter. Melhor, mesmo melhor, era a gente ir aproveitar o oco do mundo noutra parte, conceder que ele ficasse ficando. - "Vai embora inda não" - ele pediu. O violão toava bem afinado. E perguntou: -"Por que é que você não desdiz dessa festa? Vem junto, se cantar..." “-Ah, não. Mulheres quero." O Laudelim mal ouvia. Relou as cordas, ponteando, silamissol cantava. Arrastou um rasgado. Pê-Boi se despediu. - "O Rei menino... Passagens fortes! A toque de caixa... Passagens fortes... Passagens fortes..." o Laudelim deu resposta. (ROSA, 2001, p. 86-7).

Mais tarde, ao ouvir a composição do amigo Laudelim, única pessoa em quem confia, a respeito de um rei que sofrera uma emboscada, o narrador de $O$ recado do morro faz coincidir o momento pelo qual passa Pê Boi, alcunha de Pedro Orósio, com a trajetória cancioneira do Rei que morre ao se defender do ataque dos próprios guerreiros. Vejamos o instante em que se dá a sobreposição das ações do personagem Rei da canção de Laudelim com o espectador Pedro Orósio, a quem "nem lhe faltavam cinco centímetros para ter um talhe de gigante” (ROSA, 2001, p. 27):

Aí então os Sete matavam o Rei, à traição. Traição... Caifaz... Parecia coisa que tinha estado escutando aquilo a vida toda! Palpitava o errado. Traição? Ah, estava entendendo. Num pingo dum instante. Olhou aqueles, em redor. Sete? Pois não eram sete?! Estarreceu, no lugar. Soprou. - "Doidou, Pê? Que foi?” Traição, de morte, o dano dos cachorros! (ROSA, 2001, p. 103).

Contudo, a canção de Laudelim só se materializa após a longa trajetória dos cinco homens em expedição nos encontros fortuitos com personagens pouco afeitos ao convívio social, a saber, dois eremitas (Malaquias e seu irmão, Zacarias), três loucos (Guégue, Nomindômine e Coletor) e uma criança (Joãozinho), que codificam e recodificam o recado do morro da Garça - mote da canção.

Embora o processo de recodificação do recado do morro desde a sua primeira articulação mereça uma análise específica, por hora importa-nos comparar o episódio da revelação da identidade de Odisseu ao rei dos feácios após escuta das canções do aedo Demódoco, narrado no canto VIII da Odisseia, de Homero, com a descoberta da própria identidade acometida por Pedro Orósio ao ouvir a canção da morte à traição do Reimenino no conto de Guimarães Rosa, à luz da teoria do reconhecimento de Paul Ricoeur. Porém, diferentemente do ouvinte dos cantos homéricos, o leitor de $O$ recado do morro só sabe que Pedro Orósio voltará para sua terra natal no último parágrafo do conto. Esse é o estilo próprio de composição de Guimarães Rosa: entregar o ouro ao bandido apenas na última cena. Por esse motivo não nos antecipamos no tratamento dado à personagem rosiana. Querendo estabelecer uma simetria com o autor, anunciamos o reconhecimento de si, em Pedro Orósio, tal como o seu percurso ao longo da expedição pelo sertão.

Como dito anteriormente, Ricoeur estipula três capacidades inerentes ao reconhecimento de si enquanto reconhecimento de algo verdadeiro: (1) poder falar; (2) poder agir, e (3) poder narrar/narrar-se. A terceira delas, poder narrar/narrar-se - e poder ser narrado, Ricoeur associa intimamente à teoria da estruturação do gênero poético 
segundo Aristóteles, a saber, uma configuração inteligível ao emaranhado das intenções das ações dos personagens, das causas das mesmas e dos acontecimentos ao acaso.

Para compreendermos melhor tanto o reconhecimento pelo qual passa Odisseu com as canções de Demódoco, como o reconhecimento de si que sofre Pedro Orósio na composição de Laudelim, convoquemos outro filósofo da atualidade, Jacquès Rancière em A partilha do sensivel que, dialogando com o filósofo grego, chamou esse emaranhado de que é feito o gênero poético de "máquinas de compreensão complexas". Entendemos que Rancière não se opõe taxativamente a Aristóteles. Dialogando, Rancière atualiza a engenharia da Poética aristotélica ao seu modo e ao seu tempo, na narrativa contemporânea (seja ficcional ou testemunhal). Se Aristóteles reservava a verossimilhança à Poesia, Rancière (que não a inventou nem foi o primeiro a discursar sobre), estende a noção para o discurso realista. Em outras palavras, para o filósofo contemporâneo, tanto ficção como testemunho dependem de um regime de articulação de vestígios:

Aristóteles fundava a superioridade da poesia, que conta "o que poderia suceder" segundo a necessidade ou a verossimilhança da ordenação das ações poéticas, sobre a história, concebida como sucessão empírica dos acontecimentos, "do que sucedeu". A revolução estética transforma radicalmente as coisas: o testemunho e a ficção pertencem a um mesmo regime de sentido. De um lado, o "empírico" traz as marcas do verdadeiro sob a forma de rastros e vestígios. "O que sucedeu" remete pois diretamente a um regime de verdade, um regime de mostração de sua própria necessidade. Do outro, "o que poderia suceder" não tem mais a forma autônoma e linear da ordenação de ações. A "história" poética, desde então, articula o realismo que nos mostra os rastos poéticos inscritos na realidade mesma e o artificialismo que monta máquinas de compreensão complexas. (RANCIÈRE, 2009, p. 56-7).

Em outras palavras, se, por um lado, o discurso testemunho da realidade já se apresenta minimamente organizado por ter se dado numa determinada sequência que, pela sua determinação mesma, se faz necessária; por outro, o discurso ficcionalizado, valendo-se de elementos do real que atuam em função de uma operação imaginativa, carece de uma organização tal que demanda uma sequência, isto é, uma inteligibilidade própria. É no processo de preenchimento das lacunas entre um acontecimento e outro ao longo da estória que devolvemos à realidade uma interpretação minimamente satisfatória sobre ela mesma, legitimando o estatuto ambíguo da poesia: um discurso fabulado e por isso mesmo relativo ao real.

Dessa forma é que a ficção nos obriga a reler a ordenação concreta dos fatos. Mais, a própria realidade dispõe de dados que suscitam a poesia, isto é, se apresenta com elementos que excedem a ordem banal de formatação dos eventos, obrigando, por sua vez, a reinterpretá-los sob outro olhar. Nesse sentido, a composição de Pulgapé devolve a Pedro Orósio a consciência de si, ou melhor, revela ao enxadeiro sua própria identidade, isto é, seu valor, quando ele mesmo se vê rodeado pelos sete amigos desleais:

Em ver, que tinham medo dele. Ah, tinham! Aquele Ivo Crônhico, ranheta, coçador de costa de mão; aquele Jovelino - eh, bronho, - metade de si mesmo! Aquele Martinho... 
Companheiros dele? De muxoxo... Cabeçudo como esse Crônhico: pior que se meter o freio na boca dum ruim burro. E o Veneriano pé prancho, e o focinho do Martinho, e esse João Lualino assassinador de gente, todos eles. E o Nemes? Podia algum?! Súcia... (ROSA, 2001, p. 101).

É exatamente a medida da sua vida que é despertada em Pedro Orósio no momento da escuta da canção do amigo Laudelim. Essa medida se traduz de duas formas: tanto o seu porte e sua força de gigante quanto o esboçar da própria morte. Convoquemos novamente Ricoeur para tentar entender o que precisamente ecoa na consciência de Pê Boi na escuta da canção do amigo Laudelim:

Como, com efeito, um sujeito de ação poderia dar à sua própria vida uma qualificação ética se essa vida não pudesse ser reunida na forma de narrativa? A diferença com as ficções, contudo, é de tamanho, referindo-se à obscuridade dos inícios da vida, e as incertezas que pesam não apenas sobre seu fim, mas também sobre sua simples continuação. Nem o nascimento, que já ocorreu, nem a morte prevista, temida ou aceita, constituem aberturas ou encerramentos narrativos. (RICOEUR, 2006, p. 117).

É justamente a precipitação da morte do Rei menino na composição de Laudelim que desperta em Pedro Orósio a consciência de si. Em outras palavras, os versos da canção do Rei menino que inquirem seu destino: Mas, um dia, veio a Morte / vestida de Embaixador: / chegou da banda do norte / e com toque de tambor. / Disse ao Rei: - A tua sorte / pode mais que o teu valor? (ROSA, 2001 , p. 94-5), ecoam no próprio Pedro Orósio, despertando-lhe a ciência da armadilha. A vida do enxadeiro, por pertencer à ordem do real é, de fato, incerta; mas, na medida em que o trabalhador se vê circundado pelos algozes como o Rei menino o fora pelos próprios soldados, sua morte torna-se certa. Eis o recado do morro: o aviso do ardil.

Somente agora, após o dar-se conta de si em meio a uma emboscada é que Pedro Orósio reage à traição dos amigos e pode, enfim, decidir por aquilo que tanto sonhava retornar como Odisseu retornou: "Daí, com medo de crime, esquipou, mesmo com a noite, abriu grandes pernas. Mediu o mundo. Por tantas serras, pulando de estrela em estrela, até aos seus Gerais.” (ROSA, 2001, p. 105).

\section{Referências}

ARAUJO, Heloísa Vilhena de. A raiz da alma. - SP: Edusp, 1992.

GRIMAL, P. Dicionário da mitologia grega e romana. Trad. Victor Jabouille. $4^{\mathrm{a}}$ ed. RJ: Bertrand Brasil, 2000.

HEIDEGGER, M. Sobre a essência da verdade. In Os Pensadores. Trad. Ernildo Stein. SP: Abril, 1979.

HEUBECK, A.; WEST, S. e HAINSWORTH, J. B. A commentary on Homer's Odyssey, v. I. - Oxford: Clarendon, 1991.

HESÍODO, Os trabalhos e os dias. Trad. Mary Lafer. SP: Iluminuras, 2006. 
HOMERO, Odisseia. Trad. Carlos Alberto Nunes. $5^{\text {a }}$ ed. - RJ: Ediouro, 2002.

LIDDELL \& SCOTT'S Grek-English Lexicon. - Oxford: Clarendon, 1949.

MUNIZ, F. Odisseu e os limites do homem. In Cadernos de Letras da UFF, Niterói: 1998, p. 33-39.

RANCIÈRE, J. A partilha do sensível. Trad. Mônica Costa Neto. 2ª ed. - SP: 34, 2009.

RICOEUR, P. Percurso do reconhecimento. Trad. Nicolás Nyimi Campanário. SP: Loyola, 2006.

ROSA, J. G. No Urubuquaquá, no Pinhém (Corpo de Baile). 9a ed. - RJ: Nova Fronteira, 2001.

VERNANT, J.-P.; VIDAL-NAQUET, P. Mito e tragédia na Grécia antiga. Vários tradutores. - SP: Perspectiva, 2005.

VIDAL-NAQUET, P. O mundo de Homero. Trad. Jônatas Batista Neto. SP: Cia das Letras, 2002. 